\author{
С. О. Шаповалов
}

Інститут тваринництва НААНУ

\title{
РІВЕНЬ ОБМІННИХ ПРОЦЕСІВ ОРГАНІЗМУ ПОРОСЯТ ЗА УМОВ УВЕДЕННЯ КОМПЛЕКСНИХ ОРГАНІЧНИХ СПОЛУК ЕСЕНЦЙНИХ МІКРОЕЛЕМЕНТІВ
}

Розглянуто питання використання препаратів, створених на основі сполук мікроелементів ефективної альтернативи існуючих традиційних підходів до профілактики порушень обміну речовин в організмі тварин. Наведено дані про вплив мікроелементумісної композиції «Біотам» на показники крові поросят раннього віку. Досліджувана мікроелементна композиція сприяє інтенсифікації біосинтезу білків і максимальному їх накопиченню у крові тварин дослідної групи. Уведення додаткової кількості есенційних мікроелементів сприяс активним процесам розщеплення білкових структур, що потрапляють в організм з їжею, завдяки активізації панкреатичних і мембранних ферментів.

\author{
С. О. Шаповалов
}

Институт животноводства НААНУ

\section{УРОВЕНЬ ОБМЕННЫХ ПРОЦЕССОВ В ОРГАНИЗМЕ ПОРОСЯТ ПРИ УСЛОВИИ ВВЕДЕНИЯ КОМПЛЕКСНЫХ ОРГАНИЧЕСКИХ СОЕДИНЕНИЙ ЭССЕНЦИАЛЬНЫХ МИКРОЭЛЕМЕНТОВ}

Рассмотрен вопрос использования препаратов, созданных на основе соединений микроэлементов и являющихся эффективной альтернативой существующим традиционным подходам профилактики нарушений обмена веществ в организме животных. Приведены данные о влиянии микроэлементной композиции «Биотам» на показатели крови у поросят раннего возраста. Исследуемая микроэлементная композиция стимулирует биосинтез белков и приводит к максимальному их накоплению в крови животных опытной группы. Введение дополнительного количества эссенциальных микроэлементов активизирует процессы расщепления белковых структур, попадающих в организм с пищей, благодаря активизации панкреатических и мембранных ферментов.

\author{
S. O. Shapovalov \\ Institute of Animal Husbandry, NAAS of Ukraine
}

\section{METABOLISM LEVEL IN PIGLETS UNDER THE CONDITION OF INTRODUCTION OF THE COMPLEX ORGANIC COMPOUNDS OF ESSENTIAL MICROELEMENTS}

Use of preparations developed on basis of the microelements compounds is an efficient alternative to existed traditional approach to the prevention of metabolic disorders in animals. Obtained results enlarge understanding the mechanisms of antioxidant system activity and could be the basis for elaboration of scientific schemes of metabolism regulation with the help of different bioactive food supplements. Microelements complex "Biotam" stimulates proteins biosynthesis and increasing its level in the animals blood. It is proved that introduction of additional amount of microelements actuates the processes of proteolysis due to activation of pancreatic membrane enzymes.

(C) С. О. Шаповалов, 2010

96 


\section{Вступ}

Підвищення життєздатності організму молодняка свиней в ранньому постнатальному онтогенезі залишається однією з гострих проблем у сучасній біології. При цьому особлива увага приділяється контролю обмінних процесів в організмі тварин у різні періоди їх продуктивного циклу, у тому числі на рівні взаємодії «організм матері - плід - новонароджена тварина» [5; 7; 8]. Молодняк свиней народжується на ранній стадії внутрішньоутробного розвитку (на відміну від інших сільськогосподарських тварин). Він зберігає максимальну напруженість росту після народження, збільшуючи при цьому свою живу масу у 18-20 разів, порівняно з телям, яке збільшує масу лише удвічі.

3 огляду на це питання ряд дослідників зауважують, що серед основних чинників раціонального живлення в ранньому постнатальному онтогенезі є забезпечення організму необхідним набором (в оптимальних кількостях і співвідношеннях) мінеральних речовин $[1 ; 3 ; 6]$. Окрім того показано, що поросята відчувають дефіцит феруму - на 5-ту добу, купруму - на 8-му, кальцію - на 12-ту, фосфору - на 15-ту добу [7]. Актуальна проблема - розробка препаратів, здатних підвищувати антиоксидантний та імунний статус, нормалізувати метаболічні процеси у тканинах, відновлювати структуру та функції органів і систем [2; 4]. 3 огляду на це питання використання препаратів, створених на основі сполук мікроелементів, - ефективна альтернатива існуючим традиційним підходам профілактики порушень обміну речовин організму тварин і виникнення в них системних захворювань [9; 10]. Як реальна альтернатива іонним сполукам мікроелементів запропоновано синтетичні комплекси біметалів 3 органічними лігандами, утворення яких зумовлює оптимізацію, синергізм і розширення діапазону фармакологічних ефектів обох складових [4; 10]. Саме цим і пояснюється актуальність досліджень, суть яких полягає у з'ясуванні впливу мікроелементів, зокрема їх координаційних сполук, на деякі аспекти метаболізму організму поросят у ранньому онтогенезі.

Мета нашої роботи - оцінити ефективність застосування для профілактики анемій та гіпоглобулінемій новонароджених поросят комплексного мікроелементумісного препарату «Біотам», дослідити біохімічні показники та амінокислотний склад плазми крові у гострому експерименті.

\section{Матеріал і методи досліджень}

Сформовано дві групи клінічно здорових поросят за принципом пар-аналогів (вік, маса, стать) - по 12 у кожній. Усі тварини перебували на підсосі в однакових умовах утримання. Дослідну групу фарбували стійким червоним барвником та вводили на 2, 7, 21, 30-ту добу 20 мг/кг маси тіла препарату «Біотам», що містить композицію мікроелементів, у якій містяться індивідуальні комплекси металів $\mathrm{Zn}^{2+}, \mathrm{Cu}^{2+}, \mathrm{Co}^{2+}, \mathrm{Cr}^{3+}$, $\mathrm{Fe}^{3+}, \mathrm{Mn}^{2+}$ з $\mathrm{N}-2,3$-диметилфенілантраніловою (мефенаміновою) кислотою. Вміст мікроелементів в 1 грамі: $\mathrm{Zn}^{2+}-17 \mathrm{мг}, \mathrm{Cu}^{2+}-3,7, \mathrm{Co}^{2+}-0,35, \mathrm{Cr}^{3+}-0,3, \mathrm{Fe}^{3+}-14,5, \mathrm{Mn}^{2+}-$ $4,0, N$-2,3-диметилфенілантранілової кислоти - 412 мг, глюконат кальцію - 180 мг, крохмаль, цукор, аеросил - до 1 г.

Природа та мольне співвідношення мікроелементів, які входять до композиції, відповідають їх складу у металумісних ферментах. Таким чином, дослідній групі було додатково уведено протягом досліду 500 мг препарату на кожну голову. На 1, 7, 14-ту добу відбувався забір крові безпосередньо із серця, яку стабілізували гепарином. На 35-ту добу тварин було забито. У сироватці крові визначали концентрацію загального білка, альбуміну, сечовини, креатиніну, холестерину, активність аспартатамінотрансферази (АсАТ), аланінамінотрансферази (АлАТ), амілази, лужної фосфатази на 
біохімічному аналізаторі «SAPPHIRE-400» (Японія) із використанням стандартних наборів реактивів компанії «Biosystems». Концентрацію глюкози в крові визначали на апараті «Biosen» (Німеччина). Склад крові визначали на амінокислотному аналізаторі AAT-30 (Чехія).

\section{Результати та їх обговорення}

Рівень загального білка був вищим у тварин дослідної групи (на 14 \%). Таку закономірність виявлено і для білкових фракцій (рівень альбуміну вищий на 9\%), що свідчить про достатньо сталий колоїдно-осмотичний тиск та інтенсифікацію транспорту багатьох речовин ендогенного та екзогенного походження (табл. 1). Рівень глобулінів теж був вищим на $19 \%$.

Табличя 1

Біохімічні показники крові 35-добових поросят при забої, $(M \pm m, n=12)$

\begin{tabular}{|l|c|c|}
\hline \multicolumn{1}{|c|}{ Показник } & Контроль & Дослід \\
\hline Загальний білок, г/л & $52,35 \pm 2,58$ & $61,15 \pm 4,11^{*}$ \\
\hline Альбуміни, г/л & $27,62 \pm 1,87$ & $30,45 \pm 1,64^{*}$ \\
\hline Глобуліни, г/л & $24,73 \pm 2,35$ & $30,70 \pm 3,18^{*}$ \\
\hline Альбуміни / глобуліни & 1,11 & 0,99 \\
\hline Сечовина, мМ/л & $4,77 \pm 0,25$ & $4,17 \pm 0,11$ \\
\hline Креатинін, мкМ/л & $85,89 \pm 2,30$ & $0,63 \pm 0,01$ \\
\hline АЛТ, мкМ/год./см & $0,66 \pm 0,09$ & $0,52 \pm 0,01$ \\
\hline АСТ, мкМ/год./см ${ }^{3}$ & $0,50 \pm 0,01$ & $3,98 \pm 0,08$ \\
\hline Глюкоза, мМ/л & $3,96 \pm 0,07$ & $16,62 \pm 0,23^{*}$ \\
\hline Амілаза, мг/с·л & $17,86 \pm 0,35$ & $1,69 \pm 0,08$ \\
\hline Холестерин, мМ/л & $1,75 \pm 0,12$ & $141,64 \pm 17,40$ \\
\hline Лужна фосфатаза, нМ/с·л & $154,17 \pm 11,30$ & $*$ \\
\hline
\end{tabular}

Примітка: * $-p \leq 0,05$ відносно контрольної групи.

3 огляду на те, що білки відіграють в обміні речовин провідну роль, а обмінні процеси як білків, так і мікроелементів взаємопов'язані та взаємозумовлені, можна припустити, що мікроелементна композиція у тварин дослідної групи сприяє інтенсифікації біосинтезу білків і максимальному їх накопиченню у крові.

Співвідношення альбумінової та глобулінової фракцій було приблизно в однакових межах. Окрім того, при підвищенні загального білка в дослідній групі спостерігалося також підвищення рівня деяких амінокислот (табл. 2). Концентрація незамінних та лімітуючих амінокислот зросла: лізину - на $6 \%$, метіоніну - на $14 \%$, цистину - на $5 \%$, гліцину - на $20 \%(p \leq 0,05)$, решти амінокислот - від 2 до $8 \%$. Можливо, уведення додаткової кількості есенційних мікроелементів сприяє активним процесам розщеплення білкових структур, що попадають до організму з їжею завдяки активізації як панкреатичних ферментів (комплексу протеаз), так і мембранних.

При подальшому дослідженні білкового обміну встановлено, що рівень сечовини був нижчим у дослідній групі на $15 \%$, а креатиніну - на $12 \%$.

Можливо, процеси знешкодження аміаку в орнітиновому циклі йдуть активніше, підтримуючи певну кислотну ємність крові. Щодо рівня креатиніну, який є продуктом метаболізму креатину, слід зазначити, що сам креатинін, зазвичай нетоксична речовина, може перетворюватися на токсичніші метаболіти, такі як саркозин і метилгуанідин. Тому зменшення його концентрації може бути маркером сталості або мірою нормальної клубкової фільтрації, що підтверджено літературними джерелами [10; 14].

За умов подальшого дослідження обмінних процесів білкового рівня, необхідно враховувати активність гепатоспецифічних трансфераз. У нашому досліді показано, 98 
що достовірних змін активності трансаміназ у дослідній групі не виявлено, що свідчить про ферментативну нормофункцію та відсутність деструктивних змін у гепатоцитах.

Табличя 2

Амінокислотний склад крові 35-добових поросят при забої, $(M \pm m, n=12)$

\begin{tabular}{|l|c|c|c|c|}
\hline \multicolumn{1}{|c|}{ Амінокислота } & $\begin{array}{c}\text { Контроль, } \\
\text { мг/100 мг }\end{array}$ & $\begin{array}{c}\text { Контроль, мг/100 мг } \\
\text { на заг. білок }\end{array}$ & $\begin{array}{c}\text { Дослід, } \\
\text { мг/100 мг }\end{array}$ & $\begin{array}{c}\text { Дослід, мг/100 мг } \\
\text { на заг. білок }\end{array}$ \\
\hline Лізин & $1,28 \pm 0,04$ & 2,45 & $1,36 \pm 0,01$ & 2,60 \\
\hline Метіонін & $0,74 \pm 0,02$ & 1,41 & $0,87 \pm 0,07$ & 1,66 \\
\hline Треонін & $1,55 \pm 0,04$ & 2,96 & $1,47 \pm 0,07$ & 2,81 \\
\hline Аспаргінова & $2,35 \pm 0,02$ & 4,49 & $2,38 \pm 0,07$ & 4,55 \\
\hline Серин & $1,01 \pm 0,01$ & 1,93 & $1,09 \pm 0,01$ & 2,08 \\
\hline Глутамінова & $1,54 \pm 0,02$ & 2,94 & $1,67 \pm 0,04$ & 3,19 \\
\hline Пролін & $0,38 \pm 0,01$ & 0,73 & $0,40 \pm 0,01$ & 0,76 \\
\hline Цистин & $1,60 \pm 0,01$ & 3,06 & $1,69 \pm 0,02$ & 3,23 \\
\hline Гліцин & $0,60 \pm 0,04$ & 1,15 & $0,75 \pm 0,01$ & 1,43 \\
\hline Аланін & $1,55 \pm 0,09$ & 2,96 & $1,48 \pm 0,02$ & 2,83 \\
\hline Валін & $1,26 \pm 0,01$ & 2,41 & $1,20 \pm 0,08$ & 2,29 \\
\hline Ізолейцин & $0,76 \pm 0,01$ & 1,45 & $0,70 \pm 0,04$ & 1,34 \\
\hline Лейцин & $1,75 \pm 0,04$ & 3,34 & $1,80 \pm 0,04$ & 3,44 \\
\hline Тирозин & $1,04 \pm 0,06$ & 1,99 & $1,15 \pm 0,09$ & 2,20 \\
\hline Фенілаланін & $0,98 \pm 0,04$ & 1,87 & $1,04 \pm 0,07$ & 1,99 \\
\hline Гістидин & $1,42 \pm 0,01$ & 2,67 & $1,49 \pm 0,04$ & 2,85 \\
\hline Аргінін & $2,57 \pm 0,08$ & 4,91 & $2,69 \pm 0,01$ & 5,14 \\
\hline
\end{tabular}

Глюкоза в обох групах була на сталому фізіологічному рівні, проте активність амілолітичних ферментів сироватки крові в контролі була вірогідно вищою $(p<0,05)$, ніж у дослідній групі. Не встановлено достовірних змін концентрації холестерину та активності лужної фосфатази в дослідній і контрольних групах, що свідчить про направлену дію щодо оптимізації, синергізму та розширення діапазону фармакологічних ефектів уведення мікроелементумісної добавки [3; 12].

\section{Висновки}

Уведення мікроелементної композиції есенційних мікроелементів сприяє активації білкового обміну, підвищує рівень загального білка в крові, збільшує концентрацію незамінних амінокислот, знижує вміст кінцевих метаболітів білкового обміну, не порушує вуглеводний і жировий обмін.

\section{Бібліографічні посилання}

1. Глухова Э. Р. Метаболическая активность костной ткани у поросят в раннем онтогенезе: Автореф. дисс. ... канд. биол. наук. - Боровск : ВНИИ физиологии, биохимии и питания сельскохозяйственных животных, 1986. -28 с.

2. Гурьянов А. М. Оптимизация норм микроэлементов в рационах свиней / А. М. Гурьянов, В. А. Кокорев // Доклады Российской академии сельскохозяйственных наук. - 2004. - № 3. C. $76-80$.

3. Ершова В. А. Обмен меди и железа у поросят при выращивании на рационах с добавками различных форм соединений меди: Автореф. дисс. ... канд. биол. наук. - Боровск : ВНИИ физиологии, биохимии и питания сельскохозяйственных животных, 1983. - 20 с.

4. Ибрагимов Ф. Ф. Влияние кормогризина на прирост молодняка свиней при разном уровне микроэлементов в рационе // Проблемы зоотехнии. - 2000. - № 3. - С. 139-142.

5. Мацинович А. А. Оценка аналитической надежности и значимости модификации атомноабсорбционного метода при диагностике микроэлементозов // Ученые записки учреждения 
образования «Витебская государственная академия ветеринарной медицины». - 2006. -Т. 42, вып. 1, ч. 1. - С. 31-33.

6. Топорова Л. В. Органоминеральные комплексные добавки в кормлении животных / Л. В. Топорова. А. В. Лапшин, И. И. Топорова // Ветеринария сельскохозяйственных животных. 2005. - № 12. - С. 64-68.

7. Топчин А. Влияние белково-витаминно-минеральных добавок на продуктивность свиней // Свиноводство. - 2002. - Спец. вып. - С. 26-27.

8. Шушлебин В. И. Влияние антиоксидантов на содержание меди, цинка, кобальта и марганца в организме свиней в хозяйствах промышленного типа: Автореф. дисс. . . . . . канд. биол. наук. Воронеж : ВНИИ незаразных болезней животных, 1988. - 16 с.

9. Human nutrition and dietetics / J. S. Garrow et al. (ed.). - 10th ed. - London : Churchill Livingstone, 1999.

10. Hassan A. M. Glutathioneperoxidase activity in blood cells from aspiring-induced asthma patients // Ann. Clin. Biochem. - 2003. - Vol. 4, N 40. - P. 369-373.

11. Hayes J. D. Glutathionetransferases / J. D. Hayes, J. U. Flanagan, I. R. Josef // Annu. Rev. Pharmacology. Toxicology. - 2005. - Vol. 45. - P. 51-88.

12. Fomon S. J. Nutrition of normal infants. - St Louis, MO, Mosby, 1993.

13. Hurrel R. F. Role of the food industry in iron nutrition: Iron intake from industrial food products / R. F. Hurrel, S. Jacob // L. Hallberg, N. G. Asp (ed.) Iron nutrition in health and disease. - London, John Libbey et Co., 1996.

14. Method so monitoring oxidation-reduction balance and its potential role in diagnostics / L. Kocsis, A. Blazovics, Z. Pallai, J. Feher // Orv. Hetil. - 2004. - Vol. 14, N 145. - P. 761-767.

Надійшла до редколегії 08.07.2010 